\title{
Living on the edge: genetic structure and geographic distribution in the threatened Markham's Storm-Petrel (Hydrobates markhami)
}

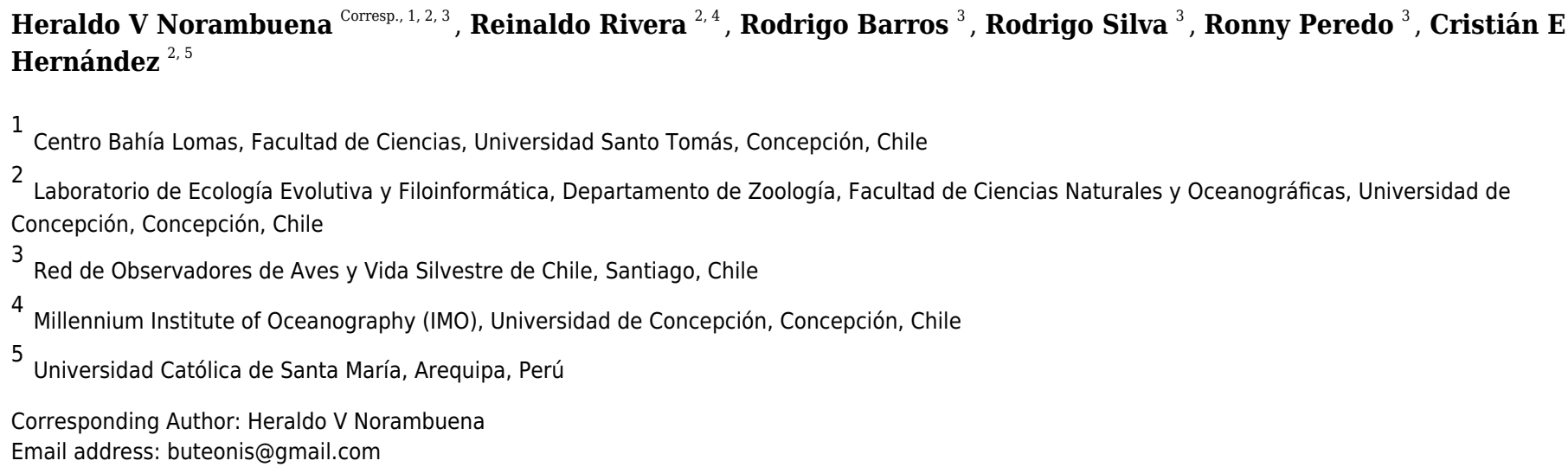

Migratory birds are threatened by habitat loss and degradation, illegal killings, ineffective conservation policies, knowledge gaps and climate change. These threats are particularly troubling in the Procellariiformes (Aves), one of the most endangered bird groups. For "storm-petrels", their cryptic breeding behavior, asynchrony between populations, and light pollution pose additional threats that contribute to increased mortality. Markham's Storm-Petrel (Hydrobates markhami), a poorly known migratory species, is a pelagic bird that breeds in dispersed colonies in the Sechura and Atacama Deserts, with asynchronous reproduction between colonies, and is highly affected by artificial lights. Considering its complex conservation scenario and singular breeding, we expected to find narrow habitat distribution conditions, strong geographic genetic structure, and spatially differentiation related to human population activities (e.g. light pollution) and the climate global change. To evaluate these predictions, we analyzed the phylogeography, current and future potential distribution based on mitochondrial gene ND1 and geographic records. The phylogeographic analyses revealed three well-supported clades (i.e. Paracas, Arica, and Salar Grande), and the geographical distribution modeled using an intrinsic conditional model (iCAR) suggests a positive relationship with the mean temperature of the wettest quarter and of the driest quarter, solar radiation, and anthropogenic disturbance. The future predictions under moderate and severe scenarios of global change indicated a drastic distribution area reduction, especially in the southern zone around Tarapacá and Antofagasta in Chile. These suggest a potential loss of unique genetic diversity and the need for conservation actions particularly focused at the edges of the $H$. markhami 
distribution. 
1 Living on the edge: genetic structure and geographic distribution in the threatened Markham's

2 Storm-Petrel (Hydrobates markhami)

3 Heraldo V. Norambuena ${ }^{1,2,3, *}$, Reinaldo Rivera ${ }^{2,4}$, Rodrigo Barros ${ }^{3}$, Rodrigo Silva ${ }^{3}$, Ronny

4 Peredo $^{3}$ \& Cristián E. Hernández $z^{2,5}$

$5{ }^{1}$ Centro Bahía Lomas, Facultad de Ciencias, Universidad Santo Tomás, Concepción, Chile.

6 2Laboratorio de Ecología Evolutiva y Filoinformática, Departamento de Zoología, Facultad de

7 Ciencias Naturales y Oceanográficas, Universidad de Concepción, Casilla 160-C, Concepción,

8 Chile.

$9 \quad{ }^{3}$ Red de Observadores de Aves y Vida Silvestre de Chile, Santiago, Chile.

$10{ }^{4}$ Millennium Institute of Oceanography (IMO), Universidad de Concepción, Concepción, Chile.

11 5Universidad Católica de Santa María, Arequipa, Perú.

12

13 Corresponding Author:

14 Heraldo V. Norambuena ${ }^{1,2,3}$

15

16 E-mail address: buteonis@gmail.com 


\section{ABSTRACT}

18 Migratory birds are threatened by habitat loss and degradation, illegal killings, ineffective conservation policies, knowledge gaps and climate change. These threats are particularly troubling in the Procellariiformes (Aves), one of the most endangered bird groups. For "storm-

21 petrels" in particular, their cryptic breeding behavior, asynchrony between populations, and light

22 pollution pose additional threats that contribute to increased mortality. Markham's Storm-Petrel

23 (Hydrobates markhami), a poorly known migratory species, is a pelagic bird that breeds in

24 dispersed colonies in the Sechura and Atacama Deserts, with asynchronous reproduction

25 between colonies, and is highly affected by artificial lights. Considering its complex

26 conservation scenario and singular breeding, we expected to find narrow habitat distribution

27 conditions, strong geographic genetic structure, and spatially differentiation related to human

28 population activities (e.g. light pollution) and the climate global change. To evaluate these

29 predictions, we analyzed the phylogeography, current and future potential distribution based on

30 mitochondrial gene ND1 and geographic records. The phylogeographic analyses revealed three

31 well-supported clades (i.e. Paracas, Arica, and Salar Grande), and the geographical distribution

32 modeled using an intrinsic conditional model (iCAR) suggests a positive relationship with the

33 mean temperature of the wettest quarter and of the driest quarter, solar radiation, and

34 anthropogenic disturbance. The future predictions under moderate and severe scenarios of global

35 change indicated a drastic distribution area reduction, especially in the southern zone around

36 Tarapacá and Antofagasta in Chile. These suggest a potential loss of unique genetic diversity and

37 the need for conservation actions particularly focused at the edges of the H. markhami

38 distribution. 


\section{INTRODUCTION}

40 Seabird populations are threatened by the loss and degradation of breeding and non-breeding

41 habitats, illegal killings, and climate change (Bairlein, 2016; Studds et al., 2017; Wilson et al.,

42 2018; Xu et al., 2019), which have induces steep declines in abundance and distribution at broad

43 scales. This problem is only exacerbated by inefficient conservation policies that do not consider

44 the conservation of breeding sites during the development of investment projects

45 (Syroechkovskiy 2006; de Boer et al., 2011), and major knowledge gaps in many species' basic

46 biology, especially in poor countries and for small-bodied species (Rodriguez et al., 2019). This

47 is particularly troubling on one of the most endangered avian groups, the Procellariiformes

48 (Class Aves) (Croxall et al., 2012), which are disproportionately threatened compared to Aves

49 overall (Rodriguez et al., 2019). For the "storm-petrels" this is not only because of its small size,

50 but also because of its cryptic breeding behavior (i.e., nocturnal colony visits, underground

51 nesting, remote and inaccessible reproduction areas), high mobility that in some cases, prevent

52 their study, management, and conservation (Brooke, 2018), and broad distribution that puts them

53 under different regulations of many national and international jurisdictions and boundaries

54 (Harrison et al., 2018). All these characteristics contribute to a high vulnerability of breeding

55 storm-petrels to anthropogenic disturbances. Additionally, one of the main threats at storm-petrel

56 breeding habitat are light pollution (e.g. Rodríguez et al., 2017). Especially for species with

57 small, restricted breeding grounds near human populations, where light pollution induces high

58 mortality of fledglings (e.g. Gineste et al., 2016).

59 The Markham's Storm-Petrel (Hydrobates markhami) is one of the least known

60 migratory seabirds in the world (Croxall et al., 2012; BirdLife International 2019). However,

61 artificial light from large cities near breeding areas are known to cause mortality from collision 
62 impacts and indirectly from predation by vultures on grounded individuals (Barros et al., 2019).

63 This small pelagic species $(21-23 \mathrm{~cm})$ is found mainly in tropical waters of the Pacific Ocean,

64 between $5^{\circ} \mathrm{N}$ and $29.9^{\circ} \mathrm{S}$, and $71^{\circ} \mathrm{W}$ and $118.02^{\circ} \mathrm{W}$ (Murphy, 1936; Spear and Ainley, 2007;

65 Howell and Zufelt, 2019). Hydrobates markhami is a colonial breeder, with five known

66 dispersed colonies in the Sechura and Atacama Deserts, specifically in saline areas (i.e. salt flats)

67 where they use fissures and cavities found under the surface on the salt flats for nesting,

68 displaying strong philopatry to their natal colonies and nesting sites (Jahncke 1993, 1994,

69 Torres-Mura and Lemus 2013, Schmitt et al. 2015, Barros et al. 2019). The northernmost colony

70 is in Paracas, Peru, where the species breeds in small, dispersed colonies up to $5 \mathrm{~km}$ from the sea

71 on the sloping ground (Jahncke, 1993, 1994). The other four colonies are in Chile, located in the

72 Coastal Atacama Desert at up to $50 \mathrm{~km}$ inland (Fig. 1; Barros et al., 2019; Medrano et al., 2019).

73 In Chile, the known colonies are (1) Arica, (2) Pampa de la Perdiz, (3) Salar Grande and (4)

74 Salar Navidad (Medrano et al., 2019). Reproduction is asynchronous between colonies (Barros et

75 al., 2019; Medrano et al., 2019). In the northern colonies in Paracas and Arica, most pairs lay

76 eggs between April and August, and chicks hatch asynchronously from July to January with a

77 peak between July and September (Jahnke, 1994; Barros et al., 2019; Medrano et al., 2019).

78 While in the colonies of Pampa Perdiz, Salar Grande and Salar Navidad breeding pairs lay eggs

79 between November and January, and chicks hatch between January and April (Barros et al.,

80 2019; Medrano et al., 2019). The species population size is estimated at 2,305-4,362 breeding

81 pairs in Peru (Jahncke, 1993, 1994) and 55,308-55,733 breeding pairs in Chile (Barros et al.,

82 2019; Medrano et al., 2019). IUCN consider H. markhami as Near Threatened (NT; BirdLife

83 International, 2019), but under Chilean classification, this species is categorized as Endangered 
84 (EN) due to decreasing population size and extended threats over the breeding colonies (Barros

85 et al., 2019; Medrano et al., 2019).

86 Currently, the genetic data and species distribution modeling could provide important

87 insights for conservation management of $H$. markhami, by examining the relationship between

88 the environment and the species distribution (Humpries et al., 2012; Field et al., 2020).

89 Additionally, it is important to include future scenarios in these combined analyses, given that

90 for many threatened species it has been suggested that their distribution under climate change

91 scenarios will experience important changes, due to translocation of habitat optima (Pecl et al.,

92 2017; Beaumont et al., 2019; Field et al., 2020) or drastic reductions in habitat suitability

93 (Cianfrani et al., 2018; Borges et al., 2019). Considering its complex conservation scenario and

94 the singular breeding habitat geography between colonies and the strong philopatry in $H$.

95 markhami (i.e. reproductive isolation and low migration) we expected to find narrow habitat

96 distribution conditions, strong genetic geographic structure, and spatially differentiation related

97 to human population activities (e.g. light pollution) and the climate global change. Under the

98 climate change context, species with unique life history traits are expected to experience more

99 changes in their distribution, which could even lead to loss of genetic diversity (Loarie et al.,

100 2009; Pecl et al., 2017). The aims of this study were to: (1) evaluate the phylogeographic

101 structure and genetic diversity distribution across most of $H$. markhami distributional breeding

102 range; (2) evaluate the effect of climatic variables and anthropogenic impact proxies on the $H$.

103 markhami geographic distribution using ecological niche modeling in a Bayesian framework; (3)

104 quantitatively assess the vulnerability to climate change under two representative concentration

105 paths (RCP) of greenhouse gas emissions, which correspond to future climate condition

106 trajectories; and (4) evaluate the effect of migration capacity on the spatial distribution models. 
108 MATERIALS AND METHODS

109 Phylogenetic analysis

110 Between November 12, 2018 and December 01, 2019, we collected blood samples from seven

111 specimens of $H$. markhami from Pampa Chaca, Arica (18 $\left.70^{\prime} \mathrm{S}, 70^{\circ} 24^{\prime} \mathrm{W}\right)$ and 9 specimens from

112 Salar Grande $\left(21^{\circ} 01^{\prime} 55^{\prime}\right.$ 'S, 6959'13'’ W) under permits from Servicio Agrícola Ganadero,

113 SAG, of Chilean government (N5022/2014 and 5742/2016). DNA was extracted from frozen

114 samples following the protocol of Fetzner (1999) using the QIAGEN DNAeasy kit. We

115 amplified the mitochondrial gene NADH dehydrogenase subunit I (ND1), via polymerase chain

116 reaction (PCR). PCR was performed in a total volume of $25 \mu \mathrm{L}$ containing $12.5 \mu \mathrm{L}$ Thermo

117 Scientific PCR Master Mix (0.05 U/ $\mu$ L Taq DNA polymerase, reaction buffer, $4 \mathrm{mM} \mathrm{MgCl2,} 0.4$

$118 \mathrm{mM}$ of each dNTP), $0.2 \mu \mathrm{M}$ of each primer and $20 \mathrm{ng}$ of template DNA. Amplification was

119 performed using the forward TMET-forward: 5'ACC-AAC-ATT-TTC-GGG-GTA-TGG-G 3'

120 and the reverse primer 16DR-reverse: 5'CTA-CGT-GAT-CTG-AGTT-CAG-ACC-GGA-G 3'

121 (Leaché and Reeder, 2002). The following thermal cycler settings were used to amplify all

122 reactions: $5 \mathrm{~min}$ at $94^{\circ} \mathrm{C}$ followed by 35 cycles of $94^{\circ} \mathrm{C}$ for $30 \mathrm{~s}, 55^{\circ} \mathrm{C}$ for $30 \mathrm{~s}$, and $72^{\circ} \mathrm{C}$ for 30

$123 \mathrm{~s}$, followed by a final extension of $72^{\circ} \mathrm{C}$ for $5 \min$ (Sausner et al., 2007). PCR products were

124 sequenced in both directions through automatic sequencing using Macrogen's ABI3730XL

125 (Seoul, South Korea). Sequences were edited using Codon Code Aligner v. 3.0.3 (CodonCode

126 Corporation, www.codoncode.com), and translated into amino acids to corroborate the absence

127 of stop codons. We got a total of eight sequences with high quality for the analysis (MZ768852

128 to MZ768859; Table S1). Moreover, five ND1 sequences from Paracas breeding site in Cerro

129 Lechuza, Peru (13ㅇ's, $\left.76^{\circ} 8^{\prime} \mathrm{W}\right)$, and one sequence from Chaca in Arica, Chile $\left(18^{\circ} \mathrm{S}, 70^{\circ} \mathrm{W}\right)$ 
130 were obtained from Sausner et al., (2017) in GenBank (Table S1). In order to avoid obtaining

131 spurious outcomes resulting from the lost phylogenetic information due to substitution

132 saturation, we tested whether the sequences used were useful for the phylogenetic analysis

133 through Xia's test (Xia et al., 2003) implemented in DAMBE v7 (Xia, 2018). Xia's test is an

134 entropy-based index that estimates a substitution saturation index (Iss) in relation to a critical

135 substitution saturation index (Iss.c), by using a randomization process with confidence intervals

136 (95\%). The proportion of invariable sites for this analysis was determined in jModeltest 2

137 (Darriba et al., 2012). The sequences of H. markhami are available in GenBank according to the

138 accession numbers provided in Table S1. As outgroups in the phylogenetic analyses, we used: $H$.

139 melania, H. microsoma, H. tethys, H. hornbyi, H. leucorhoa and H. homochroa; representatives

140 of Oceanitidae Oceanites gracilis and Fregetta grallaria; Diomedidae Thalassarche

141 chrysostoma, Thalassarche melanophrys and Phoebastria nigripes; and Procellariidae

142 Aphrodroma brevirostris (Table S1.).

143 Data were analyzed as previously described in Norambuena et al., (2018), we used both

144 Bayesian inference (BI) and maximum likelihood (ML) approaches for phylogenetic

145 reconstruction. We conducted Bayesian analyses using BEAST v. 1.10.4 program (Drummond et

146 al., 2012), using 'Yule speciation process' for the tree prior to consider the effect of divergent

147 sequences on outgroups (Drummond et al., 2012). We identified the best-fit nucleotide

148 substitution model using jModeltest 2 (Darriba et al., 2012), which indicated HKY $+\Gamma$ as the

149 best-fit model for ND1 using BIC and AICc criterion. We ran all analyses for 100 million

150 generations, and we sampled every 1,000 steps; the first $25 \%$ of the data was discarded as burn-

151 in. The convergence of MCMC analysis was examined visually in Tracer v1.6 (Rambaut and

152 Drummond, 2009). 
154 inference strategy. We ran 1,000 independent inferences and 1,000 bootstrap replicates with the

155 same nucleotide substitution model settings as for the Bayesian analysis. Support values from

1561,000 bootstrap replicates were annotated on the tree with the highest likelihood. .

157 We also inferred a haplotype network as previously described in Norambuena et al.,

158 (2018) by using the "median joining network" algorithm in Network 4.610 (Bandelt et al., 1999),

159 which is based on the sum of weighted differences (i.e. Hamming distance) between sequences.

160 Ambiguities within the network were solved according to the criteria of Crandall and Templeton

161 (1993). Finally, for each geographic area (i.e. Paracas, Arica and Salar Grande) retrieved by

162 phylogenetic analysis, we calculated in DnaSP v.5 (Librado and Rozas, 2009) the number of

163 polymorphic sites (S), haplotype diversity $(\mathrm{H})$ and nucleotide diversity ( $)$.

164

165 Occurrence data and climate variables

166 Hydrobates markhami occurrence data were obtained during 12 expeditions (see Barros et al.,

1672019 for details), literature from the Peruvian colonies (e.g. Jahncke 1993, 1994; Torres-Mura

168 and Lemus, 2013), and electronic databases (eBird, 2020). We obtained a total of 972

169 georeferenced records that were later reduced to 75 data cleaning (Supplemental Data S1). All

170 the final records correspond to confirmed and potential nests on breeding sites (Jahncke 1993,

171 1994; Barros et al., 2019). To reduce spatial autocorrelation that usually results from sampling

172 areas with a high density of locality points (clusters of points), we spatially filtered locality data

173 to allow a minimum distance of 1 kilometer between any two points.

174 The climatic variables were obtained from Wordclim version 2.1 with 2.5 minutes spatial

175 resolution (Fick and Hijmans, 2017). Additionally, we obtained environmental variables such as 
176 ultraviolet radiation (Beckmann et al., 2014), elevation, wind (Fick and Hijmans, 2017) and

177 topographic roughness (Amatulli et al., 2018). As anthropogenic impact proxies, we used the

178 databases of Human footprint (Venter et al., 2016), artificial lights (Falchi et al., 2016) and

179 human population (CIESIN, 2016). We selected the variables that were used in the models

180 through an exploratory analysis which resulted in strongly correlated variables to be eliminated.

181 We used the variance inflation factor (VIF) to evaluate the collinearity among predictors, where

182 VIF greater than 10 is a signal that the model has collinearity problems (Quinn and Keough,

183 2002). Our analyzes showed that four variables have a VIF $<3$ and four variables have a VIF

184 between 4 and 9, which are below the threshold (VIF <10) (See Fig. S1 and Table S2). Finally,

185 eight uncorrelated variables were used to perform the species distribution models (SDMs): Min

186 Temperature of Coldest Month, Temperature Annual Range, Mean Temperature of Wettest

187 Quarter, Mean Temperature of Driest Quarter, Human footprint, artificial lights, solar radiation, 188 and wind (see Table S2).

189

190 Species distribution modelling (SDM)

191 The geographical distribution of H. markhami was modeled using an intrinsic conditional model

192 (iCAR). We assume that the response variable $Z i$ is a binary variable that represents the presence

193 (1) or absence (0) of H. markhami. This approach explicitly considers spatial autocorrelation

194 (Latimer et al., 2006) to adjust an ecological process where the presence/absence of the species is

195 explained by the suitability of the habitat (Vieilledent et al., 2014), where:

$196 Z_{\mathrm{i}} \sim \operatorname{Bernoulli}\left(\pi_{\mathrm{i}}\right)$

$197 \operatorname{logit}\left(\pi_{\mathrm{i}}\right)=\mathrm{X}_{\mathrm{i}} \beta+\rho_{\mathrm{j}}(\mathrm{i})$ 
$198 \mathrm{X}_{\mathrm{i}}=$ matrix of covariates, $\beta=$ vector of the regression coefficients, $\rho$ represents the random spatial

199 effect of the observation $i$ in cell $j$, and the logit link is used to model the relationship between $\pi_{\mathrm{i}}$,

200 the covariates and spatial effect. Models were built using the package "hSDM" (Vieilledent,

201 2019) in the software R (Core Team 2019). Uninformative priors centered at zero with a fixed

202 large variance of 100 were used for all parameters involved in both ecological and observation

203 processes, while a uniform distribution was used for the variance of the spatial effects (Pennino

204 et al., 2017). We chose the model which had the lowest Deviance Information Criterion (DIC)

205 (Spiegelhalter et al., 2002), where lower values of DIC represent the best compromise between

206 fit and estimated number of parameters.

207

208 Geographical projection to the future scenarios

209 To model the geographic distribution into the future, we selected two representative

210 concentration paths (RCP) of greenhouse gases, which correspond to future climate conditions

211 trajectories of greenhouse gases adopted by the IPCC (Stocker et al., 2013). RCPs span the range

212 of the year 2100 radiative forcing, i.e. from 2.6 to $8.5 \mathrm{~W} / \mathrm{m}^{2}$ (van Vuuren et al., 2011). An RCP

2132.6 was selected as the scenario for an extremely low forcing level and 8.5 as an extremely high

214 baseline emission scenario. Three global climate models (GCMs); CCCMA, CSIRO and MIROC

215 were evaluated for the year and 2080. The climatic projections were obtained from the portal

216 http://www.ccafs-climate.org/ (Navarro et al., 2020). We explored 32 GCMs projections through

217 the GCM compareR application (Fajardo et al. 2020). CCMA, CSIRO represent models where

218 low precipitation and high temperature are represented, while MIROC is a more conservative

219 model and closest to the study area's average (e.g., Alarcón \& Cavieres, 2015; Lazo-Cancino et

220 al., 2020). In the future projections of the SDMs, we only use the variables min temperature of 
221 the coldest month, temperature annual range, mean temperature of the wettest quarter, and mean

222 temperature of the driest quarter. The variables for Human footprint, artificial lights, radiation

223 and wind were not included since there are no future predictions for these variables.

224 To quantify geographic distribution changes under future climate change scenarios, we

225 compared the current model with future projected models. Each model was converted from a

226 continuous output to a binary classification (presence/absence) using the threshold that

227 maximizes the sum of sensitivity and specificity (max SSS) (Liu et al., 2013). Then the areas

228 gained, lost, no occupancy, and no change in the future were estimated. We calculated the

229 estimated areas in square kilometers using the South American Albers Equal Area Conic

230 projection. We used SDMtoolbox module (Brown, 2014) implemented in ArcGIS 10.4.1 (ESRI,

231 2015) to calculate the areas of expansion range, contraction range, and the distribution without

232 change between present and future models.

233

234 Migration constraints

235 Since the SDMs are static in nature and do not consider the species dispersal ability, biotic

236 interactions, or population dynamics (Zurell et al., 2009, 2016; Engler et al., 2012), these do not

237 allow predicting the effect of climate change on the distribution of species in a realistic way.

238 Therefore, in our models, we consider limitations to the dispersion of H. markhami in the

239 projections, through the "Migclim" approximation (Engler et al., 2009; Engler et al., 2012). This

240 method explicitly includes the dispersal of a species, potential propagule production, geographic

241 barriers, short-distance dispersal capacity (SDD) and probability for long-distance dispersal

242 (LDD) (Engler et al., 2012). We performed the analyzes using the habitat suitability models

243 predicted by iCAR for the years 2030, 2050 and 2080. Because not all the parameters required 
244 by the algorithm are known, we opted to consider a model with barriers to dispersion, using three

245 thresholds (300, 500 and 700), where habitat suitability scales from 0 to 1000 , and the values

246 below the threshold are considered absences and above the threshold they are considered

247 presences. These thresholds allow the classification of suitable or unsuitable habitat, where cells

248 with habitat suitability $\geq$ threshold are considered as suitable, values $<$ threshold unsuitable. We

249 do not consider long-distance dispersion since H. markhami is highly philopatric (see results). To

250 set the spatial barriers for future dispersion we consider the Human Footprint as a "strong"

251 barrier, given the sensitivity of this species to human activity. The analyzes were performed for

252 the three global climate models (GCMs); CCCMA, CSIRO and MIROC. We compare the results

253 of each Migclim run selecting the best and worst simulated scenario, as follow: for the best

254 scenario, we consider one with the highest number of occupied cells, the smallest number of

255 absent cells at the end of the dispersion process, and the largest number of cells that could be

256 used in the case of "unlimited dispersal" and "non-dispersal"; and the opposite conditions was

257 considered as the worst scenario. The analyzes were performed in the MigClim 1.6 package

258 (Engler et al., 2013). All simulations for each GCMs and RCP are detailed in Table S3.

259

260

261 Genetic population structure

262 Sequences of $955 \mathrm{bp}$ in length for the ND1 locus were obtained and the result of Xia's test

263 suggests low saturation, as the critical index of substitution saturation value (Iss.c $=0.819$ ) were

264 significantly higher than the observed index of substitution saturation values (Iss $=0.514 ; \mathrm{p}<$

2650.0001 ), therefore, the sequences were deemed suitable for performing phylogenetic analyses.

266 Four haplotypes were identified defined by 17 polymorphic sites. The ML and BI trees based on

Peer] reviewing PDF | (2021:04:60607:2:0:NEW 29 Nov 2021) 
267 ND1 sequences showed identical topologies (Fig. 1A). Both trees inferred that the H. markhami

268 is monophyletic and composed of three well-supported clades (posterior probability pp of 0.9-1.0

269 and ML bootstrap support of 100). The three clades are geographically structured, with one clade

270 represented by Paracas individuals, the other by Arica, and the third by Salar Grande individuals

271 (Fig. 1A). The only geographic incongruence was in the Paracas clade where a sample from

272 Arica was the sister of all the Paracas individuals that are monophyletic with a 0.9 of pp (Fig. 273 1A).

The ND1 haplotype network revealed the same three major clades recovered from the BI

275

276

277

278

279

280

281

282

283

284

285

286

287

288

289

\section{Present and future geographic distribution}

The H. markhami distribution was mainly driven by min temperature of the coldest month (Bio 6), temperature annual range (Bio 7), mean temperature of the wettest quarter (Bio 8), mean temperature of the driest quarter (Bio 9), Human footprint (HFP), and radiation (Table 1).

Positive relationships were found between Bio 8, Bio 9, HFP, radiation and the occurrence of $H$. markhami, and negative relationship with the variables Bio 6 and Bio 7 (Table 1, Fig. S1). The highest median posterior probability of the presence of H. markhami occurs around the region of Paracas (Peru), and in a continuous area from the southern coast of Arequipa region in Peru to Antofagasta region in Chile (Fig. 2A). The spatial effect, that is, a model without considering the environmental predictors, showed to be strong for almost the entire modeled distribution range of 
290 the species (Fig. 2B). By 2080, the distribution predicted considering less severe scenarios (i.e.,

291 RCP 2.6) and severe (RCP 8.5) showed that expansion areas geographic range were greater than

292 the areas of contraction geographic range (Fig. 3 and Fig. 4) (See Table S3 and Fig. S2). The

293 MIROC model (RCP 2.6) was the only case where there would be a greater contraction of the

294 geographic range predicted in the future (Table S3). In all models and Representative

295 Concentration Pathway, a high no-occupancy geographic area is predicted, that is, areas

296 currently not occupied by the species and that are not expected to be occupied in the future.

297 Similarly, a significant area of no-change is predicted, that is, areas currently occupied by the

298 species and expected to remain occupied in the future (See Table S3 and Figs. S2-5).

299 The habitat changes predicted by the simulations indicate two highly contrasting

300 simulations (Table 2). The first one indicating a low impact on the distribution of the species in a

301 future scenario for the GCMs model MIROC (RCP 2.6) with a high number of pixels that would

302 be colonized at the beginning and end of the simulation, though, there are also numerous areas to

303 the south of their known distribution that would not be colonized (pink pixels) (Fig. 5A, Table

304 2); The second, being the worst case scenario for H. markhami (Fig. 5B, Table 2), where the

305 CCMA model (RCP 8.5) indicated a low number of occupied and colonized pixels at the end of

306 the simulation, reducing the number of areas that are suitable in the present and that would also

307 be suitable in the future (red pixels). The remaining simulations by GCMs and RCP support

308 previous results and are shown in Figs. S2-4 of the supplementary materials.

310 Discussion

311 Genetic population structure 
312 The phylogeny and haplotype network supported three main lineages within H. markhami,

313 showing a clear geographic structure associated to breeding areas in Paracas, Arica and Salar

314 Grande. The shared haplotype between Paracas and Arica suggests some degree of connectivity

315 between both areas (gene flow), however, we cannot discard that could be due to incomplete

316 lineage sorting. This result is coherent with the fact that the northern colonies (Paracas and

317 Arica) share breeding phenology, with most pairs laying eggs between April and August, and

318 chicks hatching from July to January (Jahnke, 1994; Barros et al., 2019; Medrano et al., 2019).

319 On the other hand, the differentiated haplotype from Salar Grande shares breeding phenology

320 with Pampa Perdiz and Salar Navidad, with pairs laying eggs between November and January,

321 and chicks hatching between January and April (Barros et al., 2019; Medrano et al., 2019). This

322 fact supports the importance of breeding phenologies as a key factor in explaining

323 microevolutionary processes in the Hydrobates genus. For example, for the H. castro species

324 complex, the occurrence of two different phenologies (hot and cold season) has been described

325 as a relevant mechanism for sympatric speciation (Monteiro and Furnes, 1998; Friesen et al.,

326 2007). This strong degree of geographic structure has been documented previously in Peruvian

327 diving-petrel and two Patagonian shag species that breed in colonies along the coasts of Peru,

328 Chile and Argentina (Calderón et al., 2014; Cristofari et al., 2019). However, to test the

329 relevance of the gene flow hypothesis requires additional samples improve our preliminary result

330 about geographic structured pattern and active dispersion between Paracas and Arica.

331 The biological association between breeding phenologies in H. markhami and saline areas

332 produce strong philopatry to their natal colonies and nesting sites (Jahncke, 1993, 1994; Torres-

333 Mura and Lemus, 2013; Schmitt et al., 2015; Barros et al., 2019). A large number of studies have

334 now documented that all Hydrobates species of South America use salt flats/saltpetre deposits in 
335 the coastal deserts of Sechura and Atacama to nest (Jahncke 1993, 1994; Bernal et al., 2006;

336 Ayala et al., 2007; Torres-Mura and Lemus, 2013; Barros et al., 2019; Medrano et al., 2019), and

337 even some Oceanites storm-petrels (Oceanitidae family) have been found using the same areas

338 for nesting (Barros et al., 2020).

339

340 Geographic distribution

341 Under conservative and more severe climate change scenarios, our models suggest moderate

342 reductions and strong reduction of the distribution of $H$. markhami, respectively, which agree

343 with the idea that species with specialist reproductive habitat (e.g. breeding phenology associated

344 with saline areas) are especially sensitive to the effects of rapid climate-change (Loarie et al.,

345 2009), because of the constraints imposed by this specific requirement for breeding sites (i.e.

346 niche conservatism). To date, after multiple expeditions searching for breeding sites, they have

347 only found $H$. markhami breeding in this specific environment (Barros et al. 2019, Medrano et

348 al. 2020). But considering that some petrels are able to use cavities in other substrates, such as

349 soft soil and man-made burrows (Podolsky \& Kress 1989, Bolton et al. 2004), we do not rule out

350 the capability of nest substrate plasticity.

351 The most impacted area of H. markhami distribution will be its current southern edge between

352 the Tarapacá and Antofagasta regions in Chile. Moreover, this is also the most affected area by

353 light contamination (see Barros et al., 2019), considering that $11.41 \%$ (2.269 MW) of the

354 electrical power of Chile is generated in this area and large cities dependent on mining-related

355 economy (e.g. Iquique and Antofagasta) continue to grow. The future reduction in the

356 distribution of $H$. markhami may be even more severe than suggested by our models, given that

357 we were not able to include a prediction of human footprint in the models. 
According to our results, the predicted future habitat range of $H$. markhami is likely to be

359

360

361

362

363

364

365

366

367

368

369

370

371

372

373

374

375

376

377

378

379

380

negatively affected by future climate change and will concentrate on the central portion of its

present distribution (i.e. around the Arica area). The first response of species to climate change

under GCMs MIROC RCP 2.6 scenario would be the colonization of areas around present

distribution, but under CCMA model (RCP 8.5) this colonization considerably decreased. In both

scenarios the southern distribution would not be colonized and suitable in the future (MigClim

simulation, Fig. 5). The MigClim simulations also suggest the loss of some areas in Southern

Peru and in the south of Arica colony. Unlike species with greater mobility or fewer restrictions

on reproductive habitat, that shift their distributions moving poleward and to higher elevations

(Chen et al., 2011; Pecl et al., 2017), the limited distribution of salt flats/saltpetre deposits (Sáez

et al., 2012) -key habitat for H. markhami nesting- will affect the responses of this species to

climate change. This, added to the small population of H. markhami (Barros et al., 2019), would

constrain its distribution range change by limiting its colonizing capability, and thus increasing

its extinction risk.

Most research on the response of seabird to climate change has been studies considering at-sea distribution (e.g. Wolf et al., 2010; Humpries et al., 2012). However, for seabirds such as H. markhami, the individuals at the breeding colonies could be affected by the warming of air temperature, that in severe cases could cause mortality due to overheating and physiological stress (Sydeman et al., 2012). These last conditions, related to an increase of temperature, could be particularly important in the breeding habitat of H. markhami in the Sechura and Atacama Deserts. In fact, it is expected that seabird species will respond differentially to climate change according to many different factors, including life history characteristics, diet, range, and abundance (Furness and Tasker, 2000; Sydeman et al., 2012). So, while some seabirds may fare 
381 well in warming oceans, others may become locally, regionally, or perhaps even globally extinct

382 (e.g. Kitaysky and Golubova, 2000; Jenouvrier et al., 2009; Wolf et al., 2010; Lewison et al., 383 2012).

\section{CONCLUSIONS}

386 Overall, our results of H. markhami can be useful for the design of conservation policies,

387 considering that the planning of protected areas and management should be focused on areas

388 with higher or unique genetic diversity (Midgley et al., 2003; Ayebare et al., 2018). In $H$.

389 markhami, the extinction of any local population could mean a loss of unique genetic diversity.

390 The southern portion of the H. markhami distribution (Tarapacá and Antofagasta) are the most

391 vulnerable areas according to our results and do not have any type of legal protection today. The

392 only breeding area partially protected is Paracas in Perú (Jahncke, 1993; 1994). This provides a

393 complex conservation scenario for this species, especially considering the future consequences of

394 climate change. Finally, considering the complex conservation scenario, singular breeding habits,

395 its narrow habitat distribution conditions, preliminary evidence of genetic geographic structure,

396 and spatial differentiation related to human population activities (e.g. light pollution and climate

397 global change); we highlight the urgent need for increased cooperation and governance between

398 the Peruvian and Chilean wildlife technical units, and the protection of their breeding sites in the

399 center and south of their distribution, given that the local extinctions occur closer to the border or

400 core range depending on local and regional environmental factors intermingled with human

401 impacts (Cowlishaw et al., 2009; Boakes et al., 2018).

402

403 ACKNOWLEDGEMENTS 
404 We thank Fernando Medrano for his comments on drafts of the manuscript. We thank the 'ROC' 405 volunteers that assisted the research and conservation project of Atacama storm-petrels. We 406 thank American Bird Conservancy (ABC) (Grant \#B2016-04 and \#1854A) for funding and 407 advise for our fieldwork from 2016-2020 and the Mohammed Bin Zayed Fund and the Packard 408 Foundation, for funding our fieldwork in 2017 through ABC. HVN was funded by FONDECYT409 POSTDOCTORADO 3190618 and CEH by the FONDECYT 1170815 and 1201506 grants. RR 410 was supported by Millennium Institute of Oceanography (IMO), University of Concepción,

411 Concepción, Chile. We thank an anonymous reviewer and Marcelo Rivadeneira for revisions to 412 the manuscript. 


\section{REFERENCES}

414 Alarcón D, Cavieres LA. 2015 In the Right Place at the Right Time: Habitat Representation in

415 Protected Areas of South American Nothofagus-Dominated Plants after a Dispersal

416 Constrained Climate Change Scenario. PLoS ONE 10(3): e0119952.

417 https://doi.org/10.1371/journal.pone.0119952

418 Amatulli G, Domisch S, Tuanmu M-N, Parmentier B, Ranipeta A, Malczyk J, Jetz W.

419 2018. A suite of global, cross-scale topographic variables for environmental and biodiversity

420 modeling. Scientific Data 5, 180040. doi:10.1038/sdata.2018.40.

421 Ayala L, Sanchez-Scaglioni R. 2007. A new breeding location for the Wedge-rumped Storm-

422 Petrel Oceanodroma tethys kelsalli in Peru. Journal of Field Ornithology 78(3): 303-307.

423 Ayebare S, Plumptre AJ, Kujirakwinja D, Segan D. 2018. Conservation of the endemic

424 species of the Albertine Rift under future climate change. Biological Conservation 220: 6742575.

426 Bandelt HJ, Forster P, Röhl A. 1999. Median-joining networks for inferring intraspecific 427 phylogenies. Molecular Biology and Evolution 16:37-48.

428 Barros R, Medrano F, Norambuena HV, Peredo R, Silva R, De Groote F, Schmitt F. 2019.

429 Breeding biology, distribution, and conservation status of Markham's Storm-Petrel

$430 \quad$ (Oceanodroma markhami) in the Atacama Desert. Ardea 107:75-84.

431 Barros R, Medrano F, Silva R, Schmitt F, Manilarich V, Terán D, Peredo R, Pinto C,

432 Vallverdú A, Fuchs J, Norambuena HV. 2020. Breeding sites, distribution and conservation

433 status of the White-vented Storm-petrel (Oceanites gracilis) in the Atacama Desert. Ardea

$434 \quad$ 108(2): 203-212. 
435 Beaumont LJ, Esperón-Rodríguez M, Nipperess DA, Wauchope-Drumm M, Baumgartner

436 JB. 2019. Incorporating future climate uncertainty into the identification of climate change

437 refugia for threatened species. Biological Conservation 237:230-237.

$438 \quad$ https://doi.org/10.1016/j.biocon.2019.07.013

439 Beckmann M, Václavík T, Manceur AM, Šprtová L, von Wehrden H, Welk E, Cord AM.

440 2014. glUV: A global UV-B radiation dataset for macroecological studies. Methods in

$441 \quad$ Ecology and Evolution 5:372-383.

442 Bernal M, Simeone A, Flores M. 2006. Breeding of Wedge-rumped Storm-petrels

443 (Oceanodroma tethys) in northern Chile. Ornitologia Neotropical 17(2):283-287.

444 BirdLife International. 2019. Hydrobates markhami. The IUCN Red List of Threatened

445 Species 2019: e.T22698543A156377889. https://dx.doi.org/10.2305/IUCN.UK.2019-

$446 \quad$ 3.RLTS.T22698543A156377889.en. Downloaded on 27 March 2020.

447 Boakes EH, Isaac N, Fuller RA, Mace GM, McGowan P. 2018. Examining the relationship

448 between local extinction risk and position in range. Conservation Biology 32(1): 229-239.

449 Bolton M, Medeiros R, Hothersall B, Campos A. 2004. The use of artificial breeding

450 chambers as a conservation measure for cavity-nesting procellariiform seabirds: a case study

451 of the Madeiran storm petrel (Oceanodroma castro). Biological Conservation 116: 73-80.

452 Brown JL 2014. SDMtoolbox: a python-based GIS toolkit for landscape genetic, biogeographic

453 and species distribution model analyses. Methods in Ecology and Evolution 5: 694-700.

454 Carboneras C, Jutglar F, Kirwan GM. 2020. Black Storm-petrel (Hydrobates melania). In:

455 del Hoyo, J., Elliott, A., Sargatal, J., Christie, D.A. \& de Juana, E. (eds.). Handbook of the

456 Birds of the World Alive. Lynx Edicions, Barcelona. (retrieved from

457 https://www.hbw.com/node/52598 on 2 April 2020). 
458

459

460

461

462

463

464

465

466

467

468

469

470

471

472

473

474

475

476

477

478

479

480

\section{CIESIN (Center for International Earth Science Information Network - Columbia}

University). 2016. Documentation for the Gridded Population of the World, Version 4

(GPWv4). Palisades NY: NASA Socioeconomic Data and Applications Center (SEDAC).

http://dx.doi.org/10.7927/H4D50JX4 Accessed 01 May 2020.

Crandall KA, Templeton AR. 1993. Empirical tests of some predictions from coalescent theory with applications to intraspecific phylogeny reconstruction. Genetics 134:959-969.

Cowlishaw G, Pettifor RA, Isaac NJB. 2009. High variability in patterns of population decline: the importance of local processes in species extinctions. Proceedings of the Royal Society BBiological Sciences 276:63-69.

Darriba D, Taboada GL, Doallo R, Posada D. 2012. jModelTest 2: more models, new heuristics and parallel computing. Nature Methods 9:772-772.

Drummond AJ, Suchard MA, Xie D, Rambaut A. 2012. Bayesian phylogenetics with BEAUti and the BEAST 1.8. Molecular Biology and Evolution 29:1969-1973.

eBird. 2020. eBird: An online database of bird distribution and abundance [web application]. eBird, Cornell Lab of Ornithology, Ithaca, New York. Available: http://www.ebird.org. (Accessed: Date [e.g., May 2, 2020]).

Engler R, Randin CF, Vittoz P, Czáka T, Beniston M, Zimmermann NE, Guisan A. 2009. Predicting future distributions of mountain plants under climate change: does dispersal capacity matter? Ecography 32:34-45.

Engler R, Hordijk W, Guisan A. 2012. The MIGCLIM R package-seamless integration of dispersal constraints into projections of species distribution models. Ecography 35:872-878.

ESRI 2015. ArcGIS Desktop: Release 10. Redlands, CA: Environmental Systems Research Institute.

Peer] reviewing PDF | (2021:04:60607:2:0:NEW 29 Nov 2021) 
481 Fajardo J, Corcoran D, Roehrdanz PR, Hannah L, Marquet PA. 2020. GCM COMPARER:

482 A web application to assess differences and assist in the selection of general circulation 483 models for climate change research. Methods in Ecology and Evolution 11: 656-663.

484 Falchi F, Cinzano P, Duriscoe D, Kyba CC, Elvidge CD, Baugh K, Portnov BA, Rybnikova

485 NA, Furgoni R. 2016. The new world atlas of artificial night sky brightness. Science

$486 \quad$ Advances 1:2(6):e1600377.

487 Fetzner JFC. 1999. Extracting high-quality DNA from shed reptile skins: a simplified method.

488 Biotechniques 26:7-9.

489 Fick SE, Hijmans RJ. 2017. WorldClim 2: new $1 \mathrm{~km}$ spatial resolution climate surfaces for 490 global land areas. International Journal of Climatology 37(12): 4302-4315.

491 Field RH, Buchanan GM, Hughes A, Smith P, Bradbury RB. 2020. The value of habitats of 492 conservation importance to climate change mitigation in the UK. Biological Conservation 493 248, [108619]. https://doi.org/10.1016/j.biocon.2020.108619

494 Friesen VL, Smith AL, Gómez-Díaz E, Bolton M, Furness RW, González-Solís J, Monteiro 495 LR. 2007. Sympatric speciation by allochrony in a seabird. Proc. Natl. Acad. Sci. 104:1858949618594.

497 Furness RW, Tasker ML. 2000. Seabird-fishery interactions: quantifying the sensitivity of 498 seabirds to reductions in sandeel abundance, and identification of key areas for sensitive 499 seabirds in the North Sea. Marine Ecology Progress Series 202:253-264

500 Jahncke J. 1993. Primer informe del área de anidación de la golondrina de tempestad negra 501 Oceanodroma markhami (Salvin 1883). Proc. X Congr. Nac. Biol., 1992. Lima, Perú. pp. $502 \quad 339-343$. 
503 Jahncke J. 1994. Biología y conservación de la Golondrina de Tempestad Negra Oceanodroma

504 markhami (Salvin 1883) en la Península de Paracas, Perú. APECO, Lima.

505 Jenouvrier S, Caswell H, Barbraud C, Holland M, Stroeve J, Weimerskirch H. 2009

506 Demographic models and IPCC climate projections predict the decline of an emperor penguin 507 population. Proc Natl Acad Sci 106:1844-1847.

508 Kitaysky A, Golubova EG. 2000. Climate change causes contrasting trends in reproductive 509 performance of planktivorous and piscivorous alcids. Journal of Animal Ecology 69:248-262.

510 Latimer AM, Wu SS, Gelfand AE, Silander JA. 2006. Building statistical models to analyze

$511 \quad$ species distributions. Ecological Applications 16:33-50

512 Lazo-Cancino D, Rivera R, Paulsen-Cortez K, González-Berríos N, Rodríguez-Gutiérrez R,

513 Rodríguez-Serrano E. 2020. The impacts of climate change on the habitat distribution of the

514 vulnerable Patagonian-Fueguian species Ctenomys magellanicus (Rodentia, Ctenomyidae).

$515 \quad$ Journal of Arid Environments 173: 104016

516 Leaché AD, Reeder TW. 2002. Molecular systematics of the eastern fence lizard (Sceloporus

517 undulatus): A comparison of parsimony, likelihood, and Bayesian approaches. Systematic

518 Biology 51:44-68.

519 Lewison R, Oro D, Godley B, Underhill L, Bearhop S, Wilson RP, Ainley D, Arcos JM,

520 Boersma PD, Borboroglu PG, Boulinier T, Frederiksen M, Genovart M, González-Solís

521 J, Green JA, Grémillet D, Hamer KC, Hilton GM, Hyrenbach KD, Martínez-Abraín A,

522 Montevecchi WA, Phillips RA, Ryan PG, Sagar P, Sydeman WJ, Wanless S, Watanuki

523 Y, Weimerskirch H, Yorio P. 2012. Research priorities for seabirds: improving conservation

524 and management in the 21st century. Endangered Species Research 17:93-121. 
525 Librado P, Rozas J. 2009. DnaSP v5: a software for comprehensive analysis of DNA

526 polymorphism data. Bioinformatics 25:1451-1452.

527 Liu C, White M, Newell G. 2013. Selecting thresholds for the prediction of species occurrence

528 with presence-only data. Journal of Biogeography 40(4): 778-789.

529 Loarie SR, Duffy PB, Hamilton H, Asner GP, Field CB, Ackerly DA. 2009. The velocity of

$530 \quad$ climate change. Nature 462:1052-1055.

531 Medrano F, Silva R, Barros R, Terán D, Peredo R, Gallardo B, Cerpa P, De Groote F,

532 Gutiérrez P, Tejeda I. 2019. Nuevos antecedentes sobre la historia natural y conservación de

533 la golondrina de mar negra (Oceanodroma markhami) y la golondrina de mar de collar

534 (Oceanodroma hornbyi) en Chile. Revista Chilena de Ornitología 25(1):21-30.

535 Midgley GF, Hannah L, Millar D, Thuiller W, Booth A. 2003. Developing regional and

536 species-level assessments of climate change impacts on biodiversity in the Cape Floristic

537 Region. Biological Conservation 112:87-97.

538 Monteiro LR, Furness RW. 1998. Speciation through temporal segregation of Madeiran Storm-

539 petrel (Oceanodroma castro) populations in Azores? Phil. Trans. R. Soc. Lond. B 353:845

$540-953$.

541 Murphy RC. 1936. Oceanic birds of South America. Vol. 2. MacMillan Company, New York.

542 Navarro-Racines C, Tarapues J, Thornton P, Jarvis A, Ramirez-Villegas J. 2020. High-

543 resolution and bias-corrected CMIP5 projections for climate change impact assessments. Sci

$544 \quad$ Data 7, 7, doi:10.1038/s41597-019-0343-8.

545 Norambuena HV, Van Els P, Muñoz-Ramírez CP, Victoriano PF. 2018. First steps towards

546 assessing the evolutionary history and phylogeography of a widely distributed Neotropical

547 grassland bird (Motacillidae: Anthus correndera). PeerJ, 6, e5886. 
548 Pecl GT, Araújo MB, Bell JD, Blanchard J, Bonebrake TC, Chen I-C, Clark TD, Colwell

549 RK, Danielsen F, Evengård B. 2017. Biodiversity redistribution under climate change:

$550 \quad$ impacts on ecosystems and human well-being. Science 355 (6332), aai9214.

551 Pennino MG, Arcangeli A, Prado-Fonseca V, Campana I, Pierce GJ, Rotta A, Bellido JM.

552 2017. A spatially explicit risk assessment approach: Cetaceans and marine traffic in the

553 Pelagos Sanctuary (Mediterranean Sea). PLoS ONE 12(6):e0179686.

554 Podolsky RH, Kress SW. 1989. Factors affecting colony formation in Leach's storm-petrel. The

555 Auk 106:332-336

556 Quinn GP, Keough MJ. 2002. Experimental Design and Data Analysis for Biologists.

557 Cambridge University Press, Cambridge, UK.

558 Rambaut A, Drummond AJ. 2009. Tracer version 1.6. Available at http://beast.bio.ed.ac.uk.

559 R Core Team. 2019. R: A language and environment for statistical computing. R Foundation for

560 Statistical Computing, Vienna, Austria. URL https://www.R-project.org/.

561 Sáez A, Cabrera L, Garcés M, Bogaard PVD, Jensen A, Gimeno D. 2012. The stratigraphic

562 record of changing hyperaridity in the Atacama Desert over the last 10 Ma. Earth Planet Sci

$563 \quad$ Lett 355-356.

564 Schmitt F, Barros R, Norambuena HV. 2015. Markham's Storm Petrel breeding colonies

565 discovered in Chile. Neotropical Birding 17:5-10.

566 Spear LB, Ainley DG. 2007. Storm-petrels of the Eastern Pacific Ocean: species assembly and

567 diversity along marine habitat gradients. Ornithol. Monogr. 62.

568 Spiegelhalter D, Best N, Carlin B, van der Linde A. 2002. Bayesian measures of model

569 complexity and fit. J. R. Sta.t Soc. Series B Stat. Methodol. 64:583-616. 
570 Stamatakis A. 2014. RAxML version 8: a tool for phylogenetic analysis and post-analysis of

$571 \quad$ large phylogenies. Bioinformatics 30:1312-1313.

572 Stocker TF, Qin D, Plattner GK, Alexander LV, Allen SK, Bindoff NL, Bréon FM, Church

573 JA, Cubasch U, Emori S, Forster P, Friedlingstein P, Gillett N, Gregory JM, Hartmann

574 DL, Jansen E, Kirtman B, Knutti R, Krishna-Kumar K, Lemke P, Marotzke J, Masson-

575 Delmotte V, Meehl GA, Mokhov II, Piao S, Ramaswamy V, Randall D, Rhein M, Rojas

576 M, Sabine C, Shindell C, Talley LD, Vaughan DG, Xie SP. 2013. Technical Summary. In:

577 Climate Change 2013: The Physical Science Basis. Contribution of Working Group I to the

578 Fifth Assessment Report of the Intergovernmental Panel on Climate Change [Stocker, T.F., D.

579 Qin, G.-K. Plattner, M. Tignor, S.K. Allen, J. Boschung, A. Nauels, Y. Xia, V. Bex and P.M.

580 Midgley (eds.)]. Cambridge University Press, Cambridge, United Kingdom and New York, $581 \quad$ NY, USA.

582 Sydeman WJ, Thompson SA, Kitaysky A. 2012. Seabirds and climate change: roadmap for the 583 future. Marine Ecology Progress Series 454:107-117.

584 Torres-Mura JC, Lemus ML. 2013. Breeding of Markham's Storm-Petrel (Oceanodroma

585 markhami, Aves: Hydrobatidae) in the desert of northern Chile. Revista Chilena de Historia

$586 \quad$ Natural 86:497-499.

587 van Vuuren D, Edmonds J, Kainuma M, Riahi K, Thomson A, Hibbard K, Hurtt GC, 588 Kram T, Krey Vr, Lamarque J-F, Masui T, Meinshausen M, Nakicenovic N, Smith SJ, 589 Rose SK. 2011. The representative concentration pathways: an overview. Climatic Change $590 \quad$ 109:5-31.

591 Venter O, Sanderson EW, Magrach A, Allan JR, Beher J, Jones KR, Possingham HP,

592 Laurance WF, Wood P, Fekete BM, Levy MA, Watson JE. 2016. Global Terrestrial 
593 Human Footprint Maps for 1993 and 2009. Scientific Data 3:160067.

594 https://doi.org/10.1038/sdata.2016.67.

595 Vieilledent G. 2019. hSDM: Hierarchical Bayesian Species Distribution Models. R package

596 version 1.4.1. https://CRAN.R-project.org/package=hSDM.

597 Wallace WJ, Morris-Pocock JA, González-Solís J, Quillfeldt P, Friesen VL. 2017. A

598 phylogenetic test of sympatric speciation in the Hydrobatinae (Aves: Procellariiformes).

$599 \quad$ Molecular Phylogenetics and Evolution 107:39-47.

600 Wolf SG, Snyder MA, Sydeman WJ, Doak DF, Croll DA. 2010. Predicting population

601 consequences of ocean climate change for an ecosystem sentinel, the seabird Cassin's auklet.

602 Global Change Biology 16: 1923-1935.

603 Xia X, Xie Z, Salemi M, Chen L, Wang Y. 2003. An index of substitution saturation and its 604 application. Molecular Phylogenetics and Evolution 26(1):1-7.

605 Zurell D, Jeltsch F, Dormann CF, Schröder B. 2009. Static species distribution models in

606 dynamically changing systems: how good can predictions really be? Ecography 32: 733-744.

607 Zurell D, Thuiller W, Pagel J, Cabral JS, Münkemüller T, Gravel D, Dullinger S, Normand

608 S, Schiffers KH, Moore KA, Zimmermann NE. 2016. Benchmarking novel approaches for

609 modelling species range dynamics. Global Change Biology 22: 2651-2664. 


\section{Table $\mathbf{1}$ (on next page)}

Summary of the fixed effects posterior distribution for the best model of the $H$. markhami.

Table 1. Summary of the fixed effects posterior distribution for the best model of the $H$. markhami. Mean, standard deviation (SD), and a $95 \%$ credible interval containing $95 \%$ of the probability under the posterior distribution (Q0.025-Q0.975). Bio $6=$ min temperature of coldest month, Bio $7=$ temperature Annual Range, Bio $8=$ mean temperature of wettest quarter, Bio $9=$ mean temperature of driest quarter. HFP= human footprint. 
1 Table 1. Summary of the fixed effects posterior distribution for the best model of the H. markhami.

2 Mean, standard deviation (SD), and a 95\% credible interval containing $95 \%$ of the probability

3 under the posterior distribution (Q0.025-Q0.975). Bio 6=min temperature of coldest month, Bio

$47=$ temperature Annual Range, Bio $8=$ mean temperature of wettest quarter, Bio $9=$ mean

5 temperature of driest quarter. $\mathrm{HFP}=$ human footprint.

\begin{tabular}{lcccc}
\hline & Mean & SD & Q0.025 & Q0.975 \\
\hline Intercept & -17.732 & 1.685 & -20.571 & -14.448 \\
Bio 6 & -14.658 & 4.128 & -25.068 & -9.147 \\
Bio 7 & -5.682 & 2.525 & -10.823 & -1.414 \\
Bio 8 & 5.348 & 1.902 & 1.575 & 9.054 \\
Bio 9 & 14.750 & 2.407 & 10.725 & 19.674 \\
HFP & 1.251 & 0.539 & 0.189 & 2.331 \\
Light & 0.524 & 0.758 & -1.023 & 2.061 \\
Radiation & 3.141 & 2.028 & 0.179 & 6.65 \\
Wind & 1.595 & 1.658 & -1.241 & 4.207 \\
Vrho & 75.605 & 3.492 & 71.218 & 84.312 \\
Deviance & 45.966 & 9.403 & 29.630 & 65.917 \\
\hline
\end{tabular}

6 


\section{Table 2 (on next page)}

Expected change in habitat (number of pixels) by simulation. GCMs= general circulation models , RCP $=$ Representative Concentration Pathway.

Table 2. Expected change in habitat (number of pixels) by simulation. GCMs= general circulation models, $\mathrm{RCP}=$ Representative Concentration Pathway. Threshold $=$ value to change a continuous prediction to binary. No Dispersal= number of cells that would be occupied in the case of the No Dispersal scenario. Unlimited Dispersal= Number of cells that would be occupied in the case of the Unlimited Dispersal scenario. Occupied= number of cells that are in an occupied state at the end of the given dispersal step. Absent= Number of cells that are in an unoccupied state at the end of the given dispersal step. Total Colonized= Number of cells that turned into an occupied state. Total Decolonized= Number of cells that turned into an unoccupied state during the given dispersal step. 
1 Table 2. Expected change in habitat (number of pixels) by simulation. $\mathrm{GCMs}=$ general circulation

2 models, $\mathrm{RCP}=$ Representative Concentration Pathway. Threshold $=$ value to change a continuous

3 prediction to binary. No Dispersal= number of cells that would be occupied in the case of the No

4 Dispersal scenario. Unlimited Dispersal= Number of cells that would be occupied in the case of

5 the Unlimited Dispersal scenario. Occupied= number of cells that are in an occupied state at the

6 end of the given dispersal step. Absent $=$ Number of cells that are in an unoccupied state at the end

7 of the given dispersal step. Total Colonized $=$ Number of cells that turned into an occupied state.

8 Total Decolonized $=$ Number of cells that turned into an unoccupied state during the given dispersal

9 step.

\begin{tabular}{|c|c|c|c|c|c|c|c|c|}
\hline & & & No & Unlimited & & & & \\
\hline & & Thresh- & & 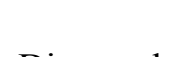 & Occupied & Absent & Total & Total \\
\hline & & old & & Dispersal & Count & Count & Colonized & Decolonized \\
\hline & & & Count & Count & & & & \\
\hline & 8.5 & 300 & 44 & 966 & 656 & 1234864 & 675 & 64 \\
\hline & 2.6 & 300 & 44 & 909 & 813 & 1234707 & 878 & 110 \\
\hline CCMA & 8.5 & 500 & 42 & 421 & 390 & 1235130 & 405 & 60 \\
\hline & 2.6 & 500 & 41 & 434 & 414 & 1235106 & 433 & 64 \\
\hline & 8.5 & 700 & 38 & 197 & 195 & 1235325 & 190 & 40 \\
\hline & 2.6 & 700 & 37 & 215 & 209 & 1235311 & 201 & 37 \\
\hline & 8.5 & 300 & 44 & 1271 & 661 & 1234859 & 699 & 83 \\
\hline & 2.6 & 300 & 44 & 1073 & 851 & 1234669 & 876 & 70 \\
\hline CSIRO & 8.5 & 500 & 42 & 691 & 490 & 1235030 & 480 & 35 \\
\hline & 2.6 & 500 & 42 & 371 & 352 & 1235168 & 385 & 78 \\
\hline & 8.5 & 700 & 37 & 351 & 292 & 1235228 & 269 & 22 \\
\hline
\end{tabular}


$\begin{array}{llllllll}2.6 & 700 & 35 & 149 & 145 & 1235375 & 169 & 69\end{array}$

\begin{tabular}{|c|c|c|c|c|c|c|c|c|}
\hline & 8.5 & 300 & 43 & 1140 & 664 & 1234856 & 700 & 81 \\
\hline \multirow[t]{5}{*}{ MIROC } & 2.6 & 300 & 44 & 1227 & 916 & 1234604 & 923 & 52 \\
\hline & 8.5 & 500 & 42 & 580 & 431 & 1235089 & 487 & 101 \\
\hline & 2.6 & 500 & 42 & 587 & 471 & 1235049 & 439 & 13 \\
\hline & 8.5 & 700 & 37 & 228 & 196 & 1235324 & 255 & 104 \\
\hline & 2.6 & 700 & 36 & 276 & 202 & 1235318 & 178 & 21 \\
\hline
\end{tabular}

10

11 


\section{Figure 1}

Map of the phylogeographic structure of Hydrobates markhami

Map of the phylogeographic structure of Hydrobates markhami showing: (A) the mtDNA ND1 Bayesian Inference (BI) and Maximum Likelihood ( $\mathrm{ML}$ ) phylogeny and the distribution of the three main clades (Upper node values represent BI posterior probabilities and down nodes values represent ML bootstrap values). (B) Haplotype network and each locality; the scale represents the sample size for each locality. At the bottom is the map with the breeding sites used for the genetics analysis. Out-groups on phylogeny are not shown. Photograph of $H$. markhami: courtesy of Fernando Díaz Segovia.

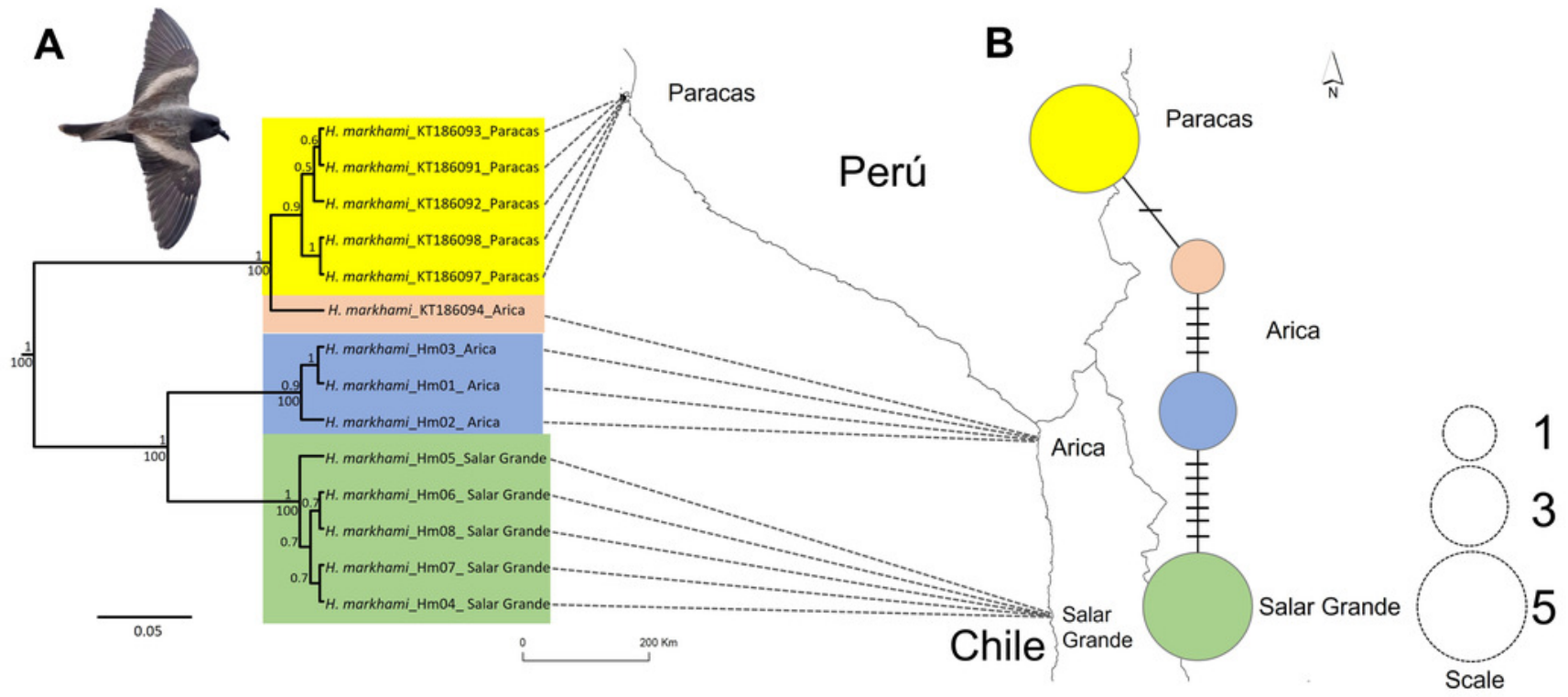


Figure 2

A) Median of the posterior probability of the presence of the Hydrobates markhami, B) Spatial effect (the spatial component represents the intrinsic spatial variability of the data without variables).
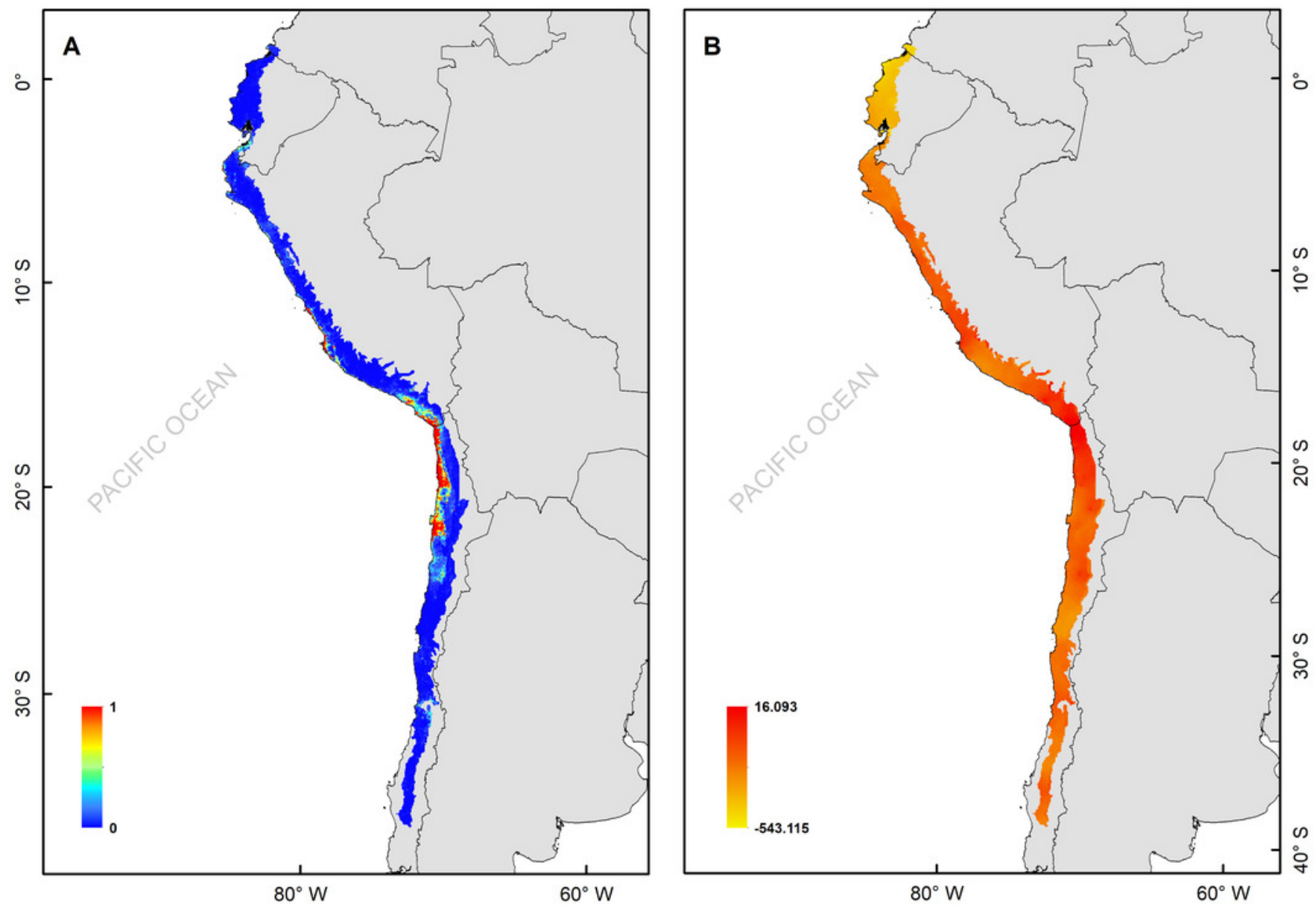
Figure 3

Habitat suitability maps for future climatic conditions predicted for 2080 under a RCP 2.6 (benign scenario).

A) Map of habitat suitability under GCMs CCCMA B) Map of habitat suitability under GCMs CSIRO, and C) Map of habitat suitability under GCMs MIROC.
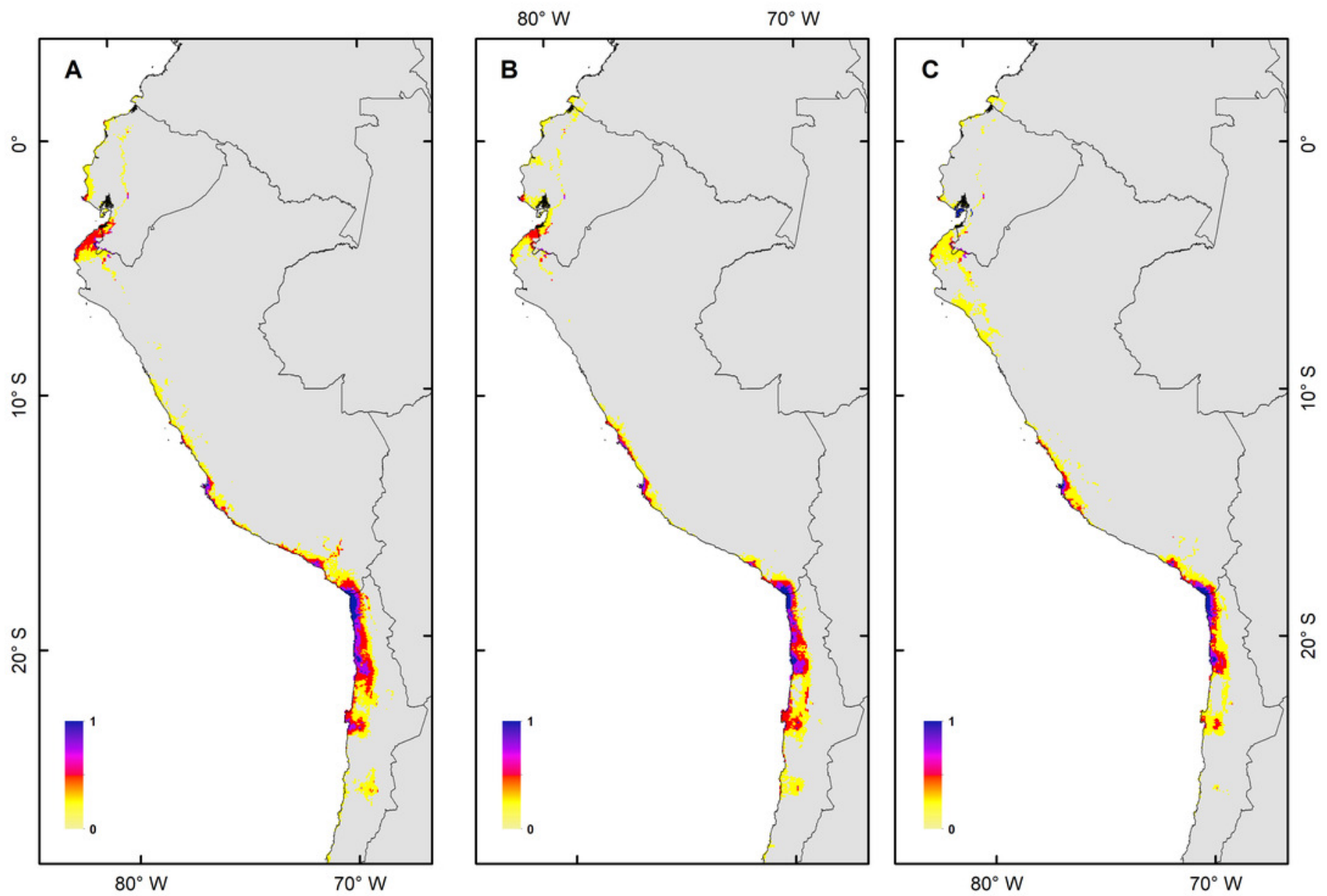
Figure 4

Habitat suitability maps for future climatic conditions predicted for 2080 under a RCP 8.5 (hard stage).

A) Map of habitat suitability under GCMs CCCMA, B) Map of habitat suitability under GCMs CSIRO, and C) Map of habitat suitability under GCMs MIROC.
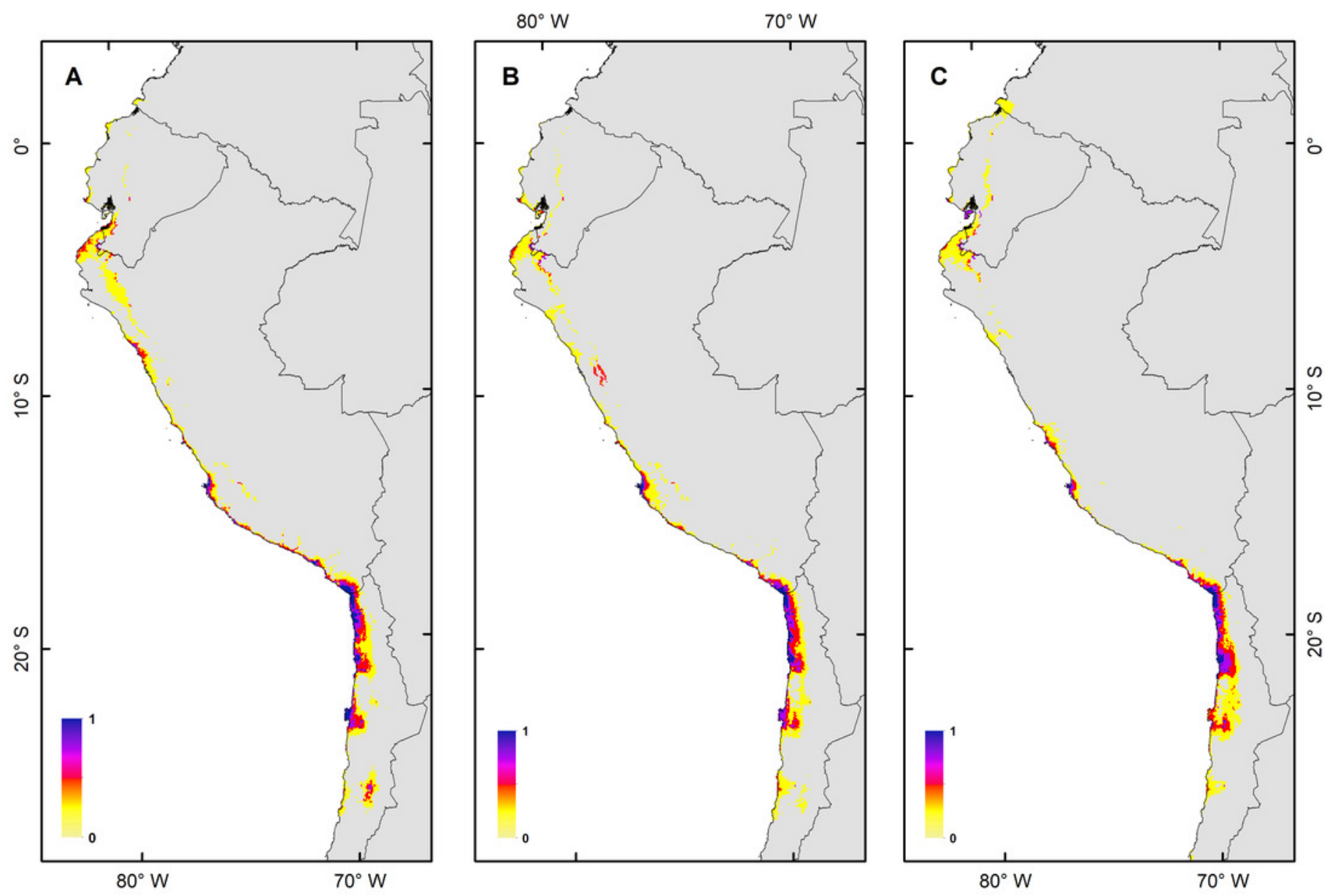
Figure 5

MIGCLIM output map Dispersal restricted future distribution of Hydrobates markhami, under two RCP.

A) Simulation for model MIROC (RCP 2.6). B) Simulation for model CCCMA (RCP 8.5). 
A
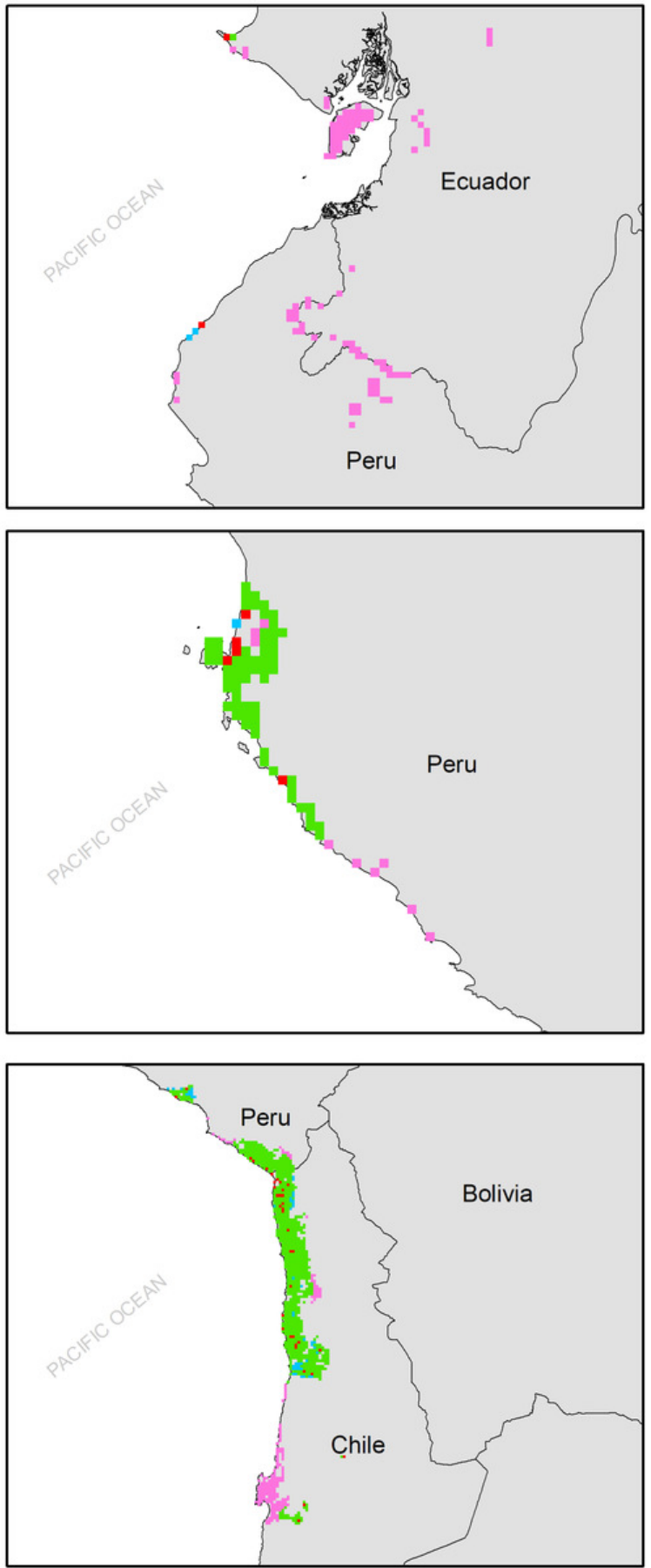

B
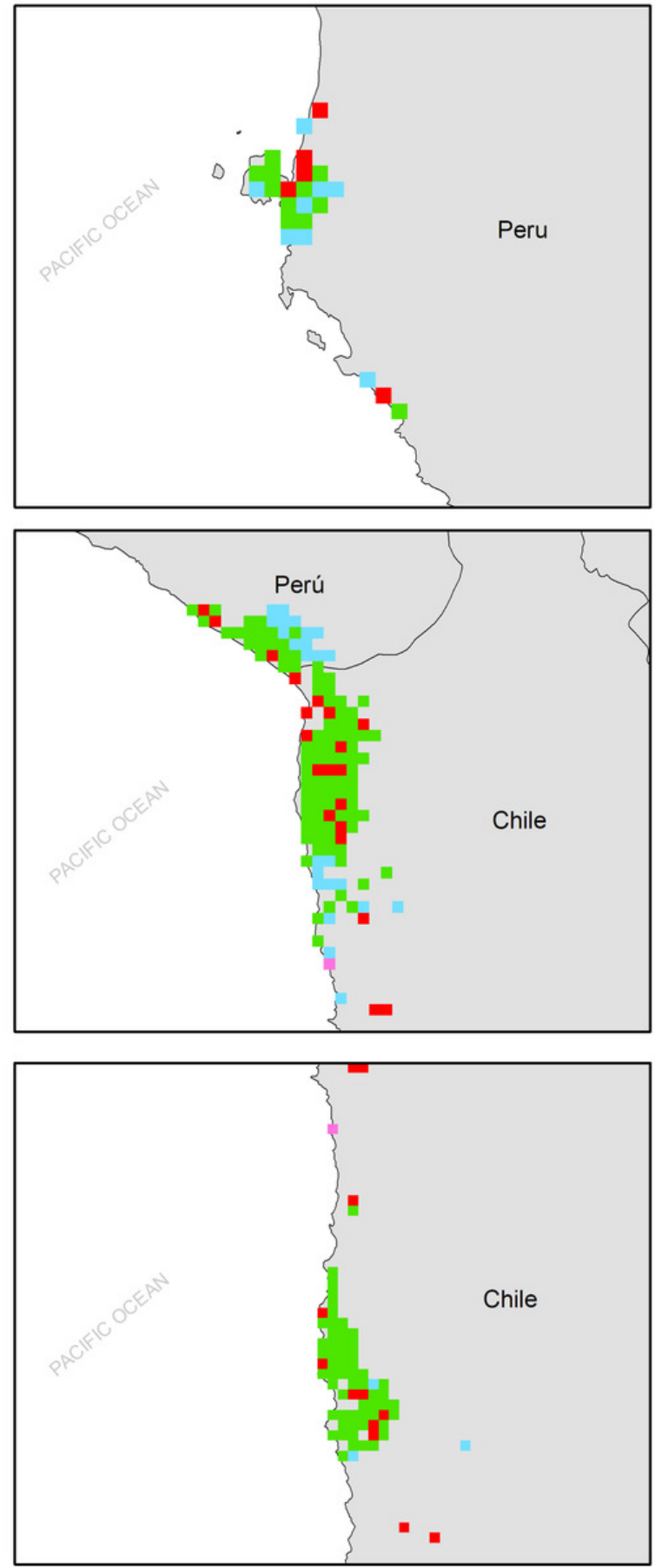

Pixels that were once occupied but turned unsuitable after environmental change

Pixel that have never been occupied and are unsuitable at the end of the simulation.

Pixels of the species initial distribution that remained suitable throughout the simulation

Pixels that have been colonized during the simulation and that remain occupied at the end of the simulation 